\title{
WIRAUSAHA KREATIF PEMBUATAN SABUN CAIR AROMA TERAPI BAGI MASYARAKAT DI BIREM RAYEUK ACEH TIMUR
}

\author{
Marjanah*, Indriaty, Setyoko \\ Progam Studi Pendidikan Biologi Fakultas Fakultas Keguruan dan Ilmu Pendidikan \\ Universitas Samudra \\ email: marjanah.bio@unsam.ac.id
}

\begin{abstract}
The Community Service Activity (PKM) conducted a creative entrepreneurship training for making aromatherapy soap which can be used as a new business opportunity for the community, especially housewives (IRT) Birem Rayeuk, Birem Bayeun Sub-District, East Aceh Regency. This activity is carried out on June 26 to July 5 2019. The activities are divided into 4 stages: (1) dissemination of activities, (2) Inventory of tools and materials (3) Training on Making Aroma Therapy liquid soap, (4) Monitoring and Evaluation. The purpose of this activity is to provide creative entrepreneurship training through the production of aromatherapy soap which can be used as a pilot for new businesses for the community and can improve the economy for the community. The results of this activity were obtained dish soap products and aroma therapy laundry soap 70 bottles of $400 \mathrm{ml}$ size with a distinctive aroma therapy from Patchouli and Citronella Fragrant extracts.
\end{abstract}

Keywords: Creative Entrepreneurship, Housewives Birem Rayeuk, Aroma Soap Therapy

\begin{abstract}
Abstrak
Kegiatan Pengabdian Kepada Masyarakat (PKM) yang dilaksanakan melakukan pelatihan wirausaha kreatif pembuatan sabun aroma terapi yang dapat digunakan sebagai peluang usaha baru bagi masyarakat, khususnya ibu-ibu rumah tangga (IRT) Birem Rayeuk Kecamatan Birem Bayeun Kabupaten Aceh Timur. Kegiatan ini dilaksanakan pada 26 Juni sampai dengan 5 Juli 2019. Pelaksanaan kegiatan dibagi dalam 4 tahapan: (1) sosialisasi kegiatan, (2) Menginventarisasi alat dan bahan (3) Pelatihan Pembuatan Sabun cair Aroma Terapi, (4) Monitoring dan Evaluasi. Tujuan kegiatan ini memberikan pelatihan wirausaha kreatif melalui pembutan sabun aroma terapi yang dapat dijadikan sebagai rintisan usaha baru bagi masyarakat dan dapat meningkatkan perekonomian bagi masyarakat. Hasil kegiatan ini diperoleh produk sabun cuci piring dan sabun cuci pakaian aroma terapi 70 botol ukuran $400 \mathrm{ml}$ dengan kekhasan aroma terapi dari ekstrak Nilam dan Sereh Wangi.
\end{abstract}

Kata Kunci: Wirausaha Kreatif, Ibu Rumah tangga Birem Rayeuk, Sabun Aroma Terapi

\section{PENDAHULUAN}

Masyarakat di desa Birem Rayeuk salah satu desa pada administratif wilayah kecamatan Birem Bayeun kabupaten Aceh Timur yang berbatasan langsung dengan kota Langsa. Desa Birem Rayeuk padat akan jumlah penduduk yang kurang lebih $500 \mathrm{KK}$.
Masyarakat sebagian besar matapencaharian sebagai petani, peternak, buruh, wiraswata dan hanya sebagian kecil beprofesi sebagai pegawai pemeriantahan dan karyawan.

Sumber penghasilan utama berasal dari kepala keluarga, sedangakan ibu-ibu rumah tangga (IRT) banyak tidak 
bekerja diluar, melainkan melakukan aktifitas pekerjaan rumah sehari-hari. Aktifitas pekerjaan rumah ibu-ibu rumah tangga tidak terlepas pada kebutuhan rumah tangga, dimana ibu-ibu rumah tangga memiliki kebutuhan mencuci baju keluarga dan mencuci piring secara terus menerus dilakukan setiap hari. Konsumsi akan sabun (brand) dijual dipasar yang digunakan oleh ibu-ibu rumah tangga memberikan muatan beban ekonomi keluarga. Pasalnya pemakaian sabun yang tergolong pada bahan habis pakai ini, digunakan secara terus menerus tanpa ada batasan waktu. Pembelian sabun juga memberikan dampak pada ekonomi keluarga secara tidak langsung.

Sabun dipasaran dibeli sebagai kebutuhan rumah tangga dengan biaya murah atau terjangkau. Namun, apabila dikalkulasikan dengan jumlah biaya pembelian sabun dengan frekuensi mencuci piring dan baju (pakaian) pada setiap keluarga dengan jumlah tidak terbatas dan waktu yang lama, akan membuat jumlah pengeluaran yang cukup besar bagi keluarga pada setiap bulan. Oleh karena itu, diperlukan penghasilan tambahan yang dapat meningkatkan perekonomian keluarga.

Wirausaha kreatif sangat diperlukan bagi masyarakat Birem Rayeuk, melihat kondisi ibu-ibu rumah tangga yang tidak memiliki penghasilan tambahan. Ibu-ibu rumah tangga dapat menghasilkan produk sabun cair yang dapat digunakan sebagai peluang usaha baru atau minimal dapat memproduksi sabun cair yang dapat digunakan secara mandiri dikeluarga.

Kegiatan pengabdian masyarakat melalui pelatihan wirausaha kreatif pembuatan sabun cair aroma terapi. Sabun cair aroma terapi yang dihasilkan akan dapat digunakan sebagai produk sabun yang digunakan setiap hari bagi kebutuhan keluarga tanpa harus membelinya di pasar. Masyarakat dapat membuat sabun cair sendiri dengan biaya pembuatan yang sangat murah, serta bahan dan alat yang digunakan dapat dibeli dengan mudah. Sabun cair yang dihasilkan memiliki kekhasan aroma terapi yang dapat diambil dari ekstrak tanaman penghasil minyak atsiri seperti sereh wangi, pala, nilam atau kayu manis.

Sabun cair dengan aroma terapi memberikan efek terapi, kesegaran dan wangi yang khas yang dapat merelaksasi pikiran jika menghirupnya. Aroma terapi dapat diperoleh dari bahan-bahan ekstrak atau penyulingan tanaman yang mengandung minyak atsiri. Bahan alam ditanaman sangat mudah ditemukan disekitar pekarangan dengan teknik penyulingan sederhana. Berbagai bahan alam dalam tanaman yang mengandung senyawa saponin tersebut, dapat digunakan sebagai busa dalam pembuatan sabun cair, karena senyawa Saponin mengandung Glikosida yang membentuk larutan kolodial dengan penambahan asam ${ }^{[4]}$. Senyawa pada saponin juga dapat digunakan sebagai anti bakteri ${ }^{[3]}$ sekaligus mengandung minyak atsiri sebagai aroma terapi ${ }^{[5]}$. Tumbuhan yang menghasilkan saponin dan minyak atsiri seperti jeruk lemon dan kayu manis sebagai anti bakteri ${ }^{[1][6]}$ [7].

Program pengabdian kepada masyarakat ini bertujuan memberikan pelatihan wirausaha kreatif pembuatan sabun cair aroma terapi bagi masyarakat khususnya ibu-ibu rumah tangga di desa Birem Rayeuk kecamatan Birem Bayeun kabupaten Aceh Timur. Masyarakat akan memperoleh pengetahuan baru dalam membuat, menyediakan sabun cair beraroma terapi sebagai produk sabun cuci dalam kebutuhan rumah tangga yang dapat digunakan sebagai sabun pencuci piring dan pencuci pakaian. Ibu-bu rumah tangga tersebut juga didorong untuk dapat memenuhi kebutuhan bahan sabun cair secara 
mandiri dirumah tangganya. Sabun cair dapat diproduksi sebagai penyediaan kebutuhan habis pakai dalam rumah tangganya, sehingga masyarakat dapat mengurangi pembelian sabun yang ada di pasar. Selain itu, masyarakat ibu-ibu rumah tangga didorong membangun usaha kreatif dalam mendorong peningkatan ekonomi keluarga.

\section{METODE PENGABDIAN}

Metode pelaksanaan kegiatan pengabdian kepada masyarakat (PKM) terdiri dari 4 tahapan kegiatan: (1) sosialisasi kegiatan, (2) persiapan alat dan bahan, (3) pelatihan pembuatan sabun cair aroma terapi, dan (4) monitoring dan evaluasi kegiatan.

Peran tim PKM dan Partisipasi mitra masyrakat ibu-ibu rumah tangga (IRT) Birem Rayeuk dapat dijelaskan sebagai berikut: (1) Peran Tim PKM: (a) Memberikan pengetahuan dasar mengenai sabun aroma terapi, (b) Menginventarisasi alat dan bahan, (c) Memberikan pelatihan pembuatan sabun cair aroma terapi, (d) Melakukan monitoring dan evaluasi kegiatan. Peran mitra masyarakat IRT : (a) Memberikan tempat dan waktu selama kegiatan berlangsung, (b) Partisiapatif masyarakat dalam kegiatan program pengabdian kepada masyarakat, (c) Mempraktekan kegiatan secara mandiri dirumah.

\section{HASIL DAN PEMBAHASAN}

Kegiatan ini dilaksanakan pada 26 Juni sampai dengan 5 Juli 2019 bagi masyarat Ibu-ibu Rumah Tangga (IRT) di desa Birem Rayeuk kecamatan Birem Bayeun kabupaten Aceh Timur. Pelaksanaan kegiatan pengabdian kepada masyarakat ini menjadi 4 kegiatan utama.

\section{Sosialisasi Kegiatan PKM}

Sosialisasi dilakukan oleh tim Pengabdian kepada masyarakat yaitu oleh ketua Tim Ibu Dra. Marjanah, dan 2 Anggota Tim Ibu Indriaty, M.Pd dan Bapak Setyoko, M.Pd dan melibatkan 2 orang mahasiswa program Studi Pendidikan Biologi, sedangkan Mitra dalam kegiatan sosialisasi kegiatan PKM dihadiri oleh 31 peserta dari masyarakat yang terdiri Ibu-ibu rumah tangga (IRT) dapat dilihat pada Gambar 1.

Pada tahap sosilaisasi ini kegiatan dibuka langsung dirumah warga masyarakat setempat secara resmi, kemudian anggota tim pengabdian kepada masyarakat memberikan penjelasan tentang sabun aroma terapi yang akan dibuat nantinya. Sabun aroma terapi yang dimaksudkan dengan menggunakan berbagai bahan campuran kimia dan organik ekstraksi dari nilam atau sereh wangi. Kegiatan dilakukan dengan diskusi terbuka saling tanya-jawab dan diakhiri dengan penutup dengan menentukan jadwal pertemuan selanjutnya.

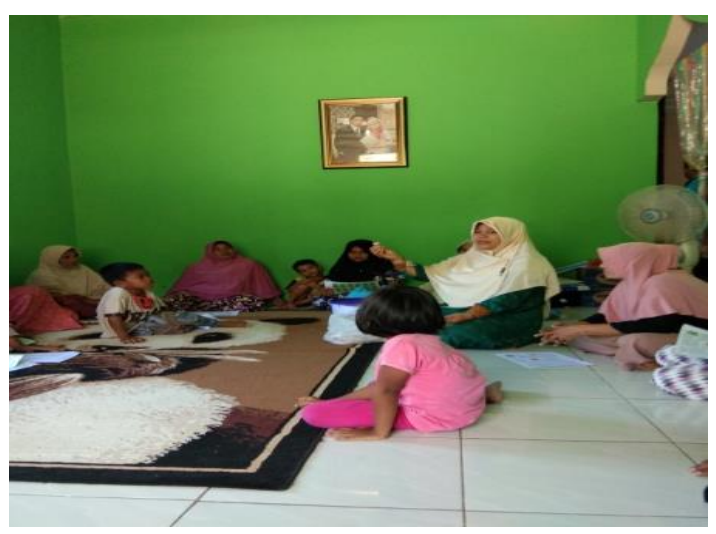

Gambar 1. Sosialisasi Kegiatan PKM Pembuatan Sabun Cair Aroma Terapi.

\section{Inventarisasi Alat dan Bahan}

Inventarisasi alat dan bahan dilakukan oleh tim PKM dan Mitra. Alat dan bahan yang diperlukan secara teknik dapat disediakan langsung oleh mitra, sedangkan alat dan bahan utama 
langsung disediakan oleh tim PKM. Alat dan bahan yang digunakan dalam pembuatan sabun sebagian besar menggunakan bahan Kimia. Aroma terapi atau pembunuh bakteri dapat menggunakan ekstrak kayu manis sebagai pembunuh pertumbuhan bakteri [2].

Alat yang digunakan dalam kegiatan ini yaitu: Botol, Takaran air, Baskom, Ember, Pengaduk, dan Sendok. Bahan yang digunakan yaitu: Texapon (Sodium Lauril Sulfat/SLS) berfungsi penghasil busa dan mengangkat kotoran, Natrium Sulfat, $\left(\mathrm{Na}_{2} \mathrm{SO}_{4}\right)$ berfungsi pelarut air dan gliserol, Foam Booster berfungsi memperbanyak busa pada sabun, Natrium Klorida ( $\mathrm{NaCl}$ ) befungsi pengental sabun cair, Asam Etilen Diamin (EDTA), Gliserin berfungsi melembutkan pada kulit, Fisatif berfungsi sebagai pengangkat kotoran dan noda, Air berfungsi sebagai pelarut semua zat, Parfum berfungsi sebagai pengharum sabun, Cocoamide Diethanol Amine berfungsi sebagai pembentuk gel, Ekstrak Nilam dan Sereh Wangi berfungsi sebagai aroma terapi sabun cair. Alat dan bahan dapat dilihat pada Gambar 2.

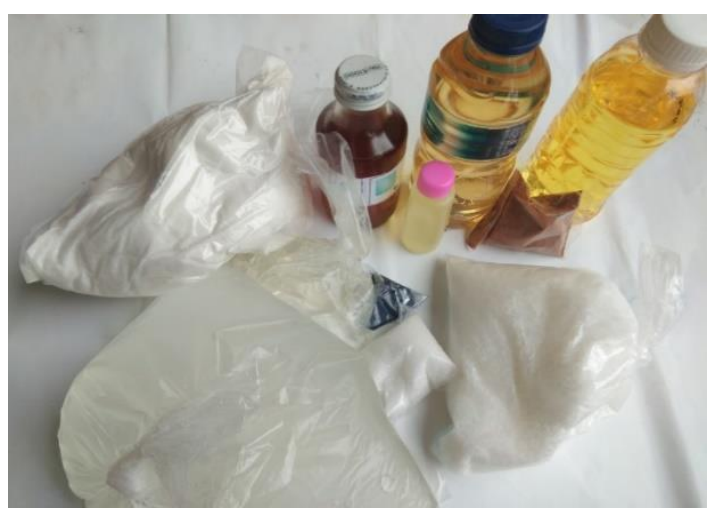

Gambar 2. Bahan dan Alat yang digunakan dalam pembuatan Sabun cair Aroma Terapi.

\section{Pelatihan Pembuatan Sabun Cair Aroma Terapi}

Pelatihan pembutan sabun cair aroma terapi dilakukan dengan simulasi langsung oleh Tim Pengabdian kepada Masyarakat (PKM) kepada mitra. Kegiatan awal dengan menjelaskan fungsi dari masing-masing bahan dan alat yang digunakan pada Gambar 3 . Selanjutnya Tim pengabdian memberikan Brosur panduan tatacara pembuatan sabun cair kepada mitra dengan menjelaskan prosedur langkah kerja, dapat dilihat pada Gambar 4 dan Gambar 5.

Pembuatan sabun cair aroma terapi dengan tahapan menimbang semua bahan bahan kimia sesuai dengan takaran yang digunakan, dalam pelaksnaan pengabdian ini menggunakan takaran yang disesuaikan dengan jumlah botol yang tersedia. Bahan yang digunakan dalam pelatihan ini menggunakan proposi sabun cair aroma terapi 70 botol sabun ukuran 400 $\mathrm{ml}$ dalam satu kali pembuatan sabun cair selama program PKM.

Takaran bahan yang digunakan dalam pembutan sabun cair aroma terapi diantaranya $\mathrm{NaCl} 20$ gram, $\mathrm{Na}_{2} \mathrm{SO}_{4} 35$ gram atau $3 / 4$ dari bahan yang digunakan, Texapon 120 gram, bahan lainnya seperti Fisatif, Camperlan $20 \mathrm{ml}$, EDTA 1,1 gram Foam Booster $10 \mathrm{ml}$, Gliserin 1 $\mathrm{ml}$, parfum $3 \mathrm{ml}$, Pewarna dan minyak nilam atau sereh wangi $1 \mathrm{ml}$.

Pencampuran bahan-bahan yang digunakan dalam wadah baskom atau ember. Larutan yang pertama kali di letakan secara berurutan untuk memperoleh hasil yang sempurna dalam pembuatn sabur cair yaitu garam, Natrium sulfat, texapon dilarutkan dalam air. Setelah itu bahan-bahan lainnya dicampurkan seperti fisatif, camperlan dan pewarna diaduk hingga merata dibutuhkan air kurang lebih 1 liter.

Proses pembuatan sabun cair dilakukan dengan pengadukan sesering mungkin hingga bahan Natrium Sulfat berbentuk butiran putih dapat larut dalam air. Untuk pengadukan manual diperlukan larutan diendapkan kurang 
lebih satu malam, sedangkan pengadukan otomatis menggunakan mesin tidak perlu diendapkan. Tahap akhir dengan pemberian ekstrak minyak nilam atau serh wangi pada larutan sabun cair. Ekstrak nilam ini berfungsi sebagai aroma terapi pada sabun cair yang dibuat dalam program pengabdian kepada masyrakat.

Hasil program pengabdian kepada masyrakat ini telah menghasilkan 70 botol sabun cair aroma terapi berukuran $400 \mathrm{ml}$, yang dapat dipergunaka sebagai sabun pencuci baju dan sabun pencuci piring. Produk sabun aroma terapi dapat dilihat pada Gambar 6. Sabun yang dibuat diberikan kepada seluruh peserta kegiatan pengabdian kepada masyarakat.

Estimasi wirausaha baru dalam pembuatan sabun cair aroma terapi yaitu: Modal awal pembuatan sabun untuk jumlah 70 botol adalah Rp. 240.000,-. Jika harga 1 botol sabun cair aroma terapi dijual dengan konsumen seharga Rp. 8.000,-/perbotol, maka total penjualan keuntungan kotor (bruto) akan diperoleh Rp. 620.000,-. Jika keuntungan kotor dikurangi dengan modal awal maka keuntungan bersih (netto) yang dapat diterima $\mathrm{Rp}$. 380.000,-. Pembuatan sabun cair aroma terapi ini sangat menguntungkan bagi masyarakat jika dijadikan sebagai wirausaha.

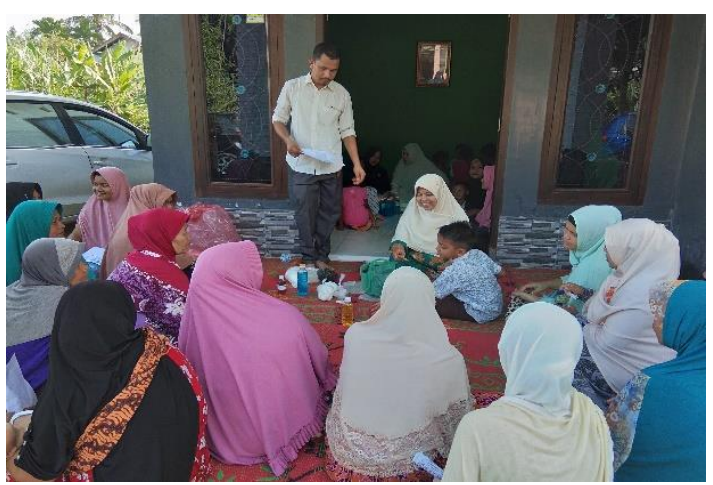

Gambar 3. Pengenalan dan Penjelasan Fungsi Alat dan Bahan yang digunakan
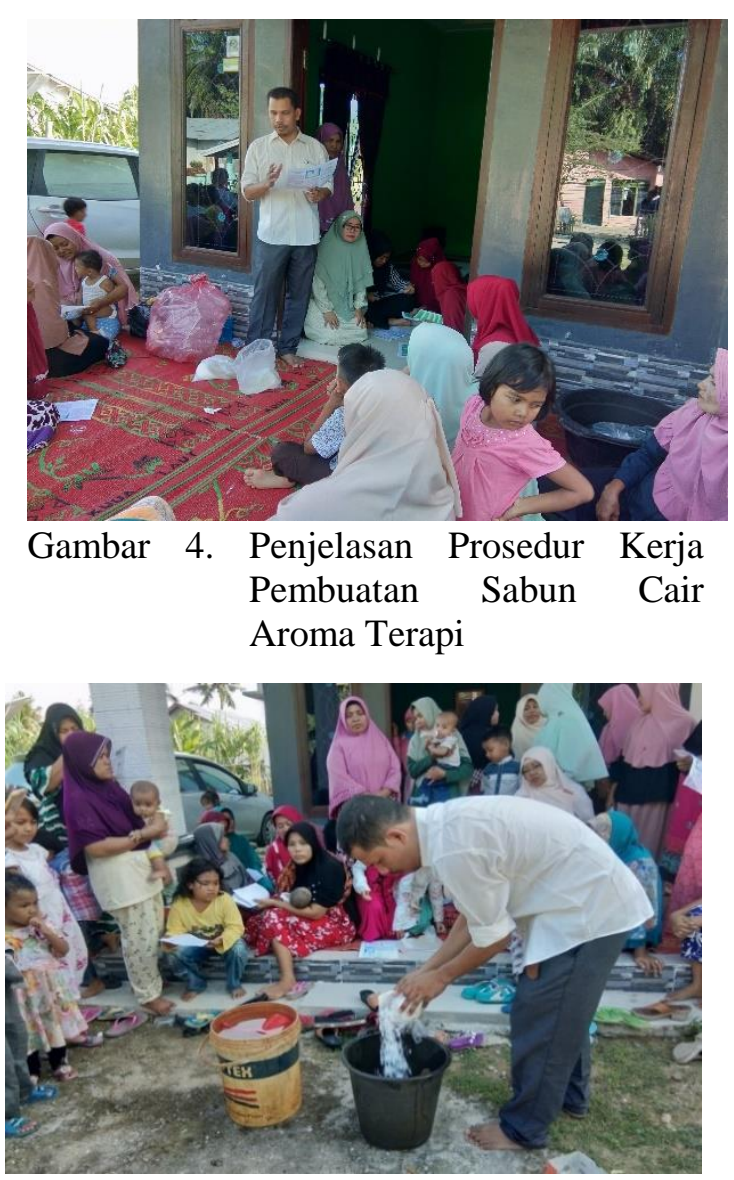

Gambar 5. Simulasi Pelatihan Pembuatan Sabun Cair Aroma Terapi

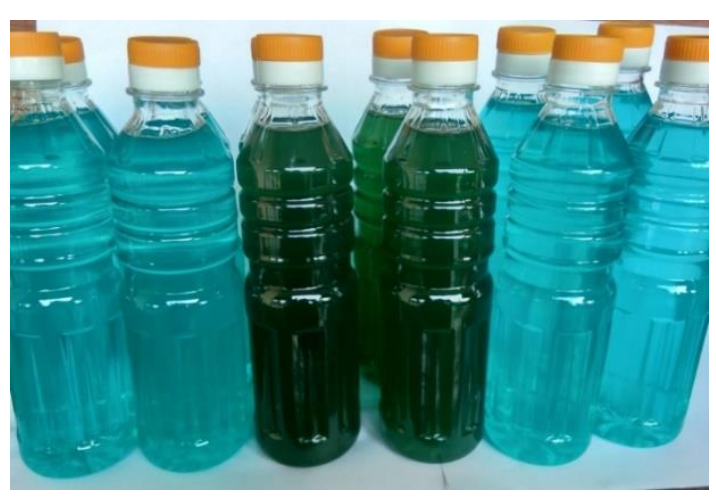

Gambar 6. Produk Sabun Cair Aroma Terapi

\section{Monitoring dan Evaluasi (Monev)}

Monitoring dan evaluasi

(Monev) program pengabdian kepada masyarakat dilakukan tim PKM dalam rangka mengukur tingkat keberhasilan program. Monitoring dilakukan setelah 
pelaksaaan pelatihan pembuatan sabun cair aroma terapi. Mitra Ibu-ibu Rumah (IRT) Birem Bayeun selama monitoring dilakukan belum sepenuhnya dapat membuat sabun cair aroma terapi secara individu, namun dapat membuat secara berkelompok. Hal ini, dapat disebabkan pengetahuan bahan-bahan kimia yang digunakan masih belum familiar bagi mitra, terkhusus profesinya sebagai ibu rumah tangga. Evaluasi program dilakukan dengan pendampingan lanjutan khusus kepada mitra Ibu-ibu rumah tangga dalam berwirausaha usaha baru. Evaluasi dimulai dari modal usaha, pembentukan kelompok, pembuatan sabun skala industrui rumah tangga mikro, dan strategi pemasaran produk sabun kepada konsumen.

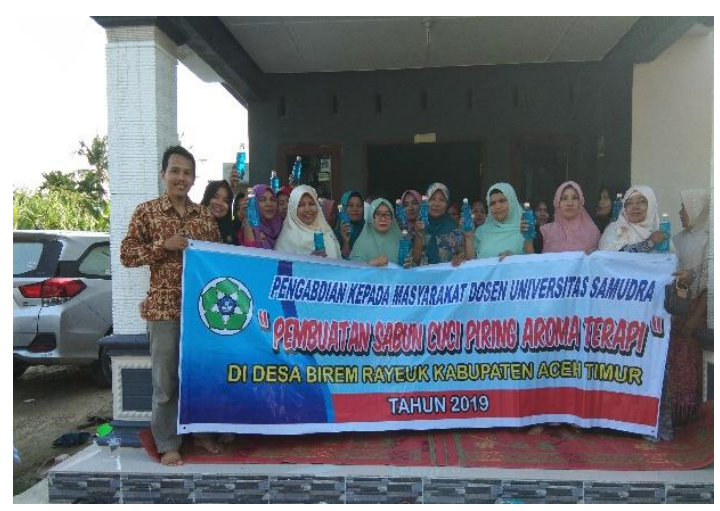

Gambar 7. Foto Bersama Tim PKM dan Mitra Ibu-ibu IRT Birem Bayeun

\section{SIMPULAN}

Kegiatan Pengabdian Kepada Masyarakat (PKM) dilaksanakan di masyarakat khususnya ibu-ibu rumah tangga (IRT) di desa Birem Rayeuk Kecamatan Birem Bayeun Kabupaten Aceh Timur. Kegiatan ini dilaksankan pada 26 Juni sampai dengan 5 Juli 2019. Pelaksanaan kegiatan Pengabdian kepada masyarakat terdiri dari 4 tahapan kegiatan: (1) sosialisasi kegiatan, (2) persiapan alat dan bahan, (3) pelatihan pembuatan sabun cair aroma terapi, dan (4) monitoring dan evaluasi kegiatan. Hasil produk kegiatan ini menghasilkan sabun cuci piring dan sabun cuci pakaian aroma terapi 70 botol ukuran $400 \mathrm{ml}$ dengan kekhasan aroma terapi dari ekstrak Nilam dan Sereh Wangi. Pelatihan wirausaha kreatif melalui pembuatan sabun aroma terapi yang dapat dijadikan sebagai rintisan usaha baru bagi masyarakat.

\section{UCAPAN TERIMAKASIH}

Ucapan terimakasih penulis ucapkan kepada LPPM dan PM Universitas Samudra yang telah memberikan dana dalam pelaksanaan kegiatan Pengabdian Kepada Masyarakat melalui Program Hibah Pengabdian Kepada Masyarakat (PKM) Tahun 2019. Serta ucapan terimakasih kepada Masyarakat khususnya Ibu-ibu Rumah Tangga (IRT) desa Birem Rayeuk kecamatan Birem Bayeun kabupaten Aceh Timur selaku mitra dalam pelaksanaan program ini

\section{DAFTAR PUSTAKA}

[1]. La Sakka. 2018. Indentifikasi senyawa Alkaloid, Flavonoid, Saponin dan Tanin pada Jeruk Nipis (Citrus aurantifiolia) di Kabupaten Bone Kecamatan Lamuru Menggunakan Metode Infusa. Jurnal Ilmiah Kesehatan Diagnosis, 6 (12), p. 2302-2531

[2]. Mubbarak, Z., Chrismirina, S dan Qamari, C.A. 2016. Aktivitas Antibakteri Ekstrak Kayu Manis (Cinnaomum burmanii) terhadap Pertubuhan Enterecoccus Faecalis. 8 (1), p. 1-76.

[3]. Muchtaridi. 1996. Penelitian pengembangan minyak atsiri sebagai aromaterapi dan potensinya sebagai produk sediaan farmasi Jurnal Teknologi Industri Pertanian. 17(3). p.80-88.

[4]. Mukhollad W. 2019. Saponin. www.academia.edu diakses 19 Februari 2019 
[5]. Suradi K, Gumilar J, Yohana G H R, Hidayatulloh. 2017. Kemampuan serbuk serai (Cymbopogon citratus) menekan peningkatan total bakteri dan keasaman (ph) dendeng domba selama penyimpanan. Jurnal ilmu Ternak. 17 (2), p. 106-111.

[6]. Tanjung K N, Sudarno, Sulmartiwi L. 2008. Efektivitas ekstrak kulit jeruk lemon (Citrus limonum) terhadap daya Hambat pertumbuhan Aeromonas hydrophila Secara in vitro. Jurnal Berkala Ilmiah Perikanan 3 (1), p. 38-42.

[7]. Wijayanti, W.A., Zetra, Y., dan Burhan, P., 2009, Minyak Atsiri dari Kuli Batang Cinnamomum burmannii (Kayu Manis) dari Famili Lauraceae sebagai Insektisida Alami, Antibakteri, dan Antioksidan. Prosiding Seminar Nasional di Institut Teknologi Sepuluh November. 